\title{
Daytime Photochemical Pollutant Transport over a Tributary Valley Lake in Southwestern British Columbia
}

\author{
I. G. McKendry And D. G. Steyn \\ Atmospheric Science Programme, University of British Columbia, Vancouver, British Columbia, Canada \\ R. M. BANTA \\ NOAA/Environmental Technology Laboratory, Boulder, Colorado \\ W. Strapp AND K. AnlauF \\ Cloud Physics Research Division, Atmospheric Environment Service, Downsview, Ontario, Canada \\ J. PotTIER \\ Environmental Conservation Branch, Environment Canada, Vancouver, British Columbia, Canada
}

(Manuscript received 10 February 1997, in final form 20 June 1997)

\section{ABSTRACT}

\begin{abstract}
Tethersonde, lidar, aircraft, and surface chemistry measurements from an intensive field campaign (Pacific '93) in the Lower Fraser Valley (LFV) demonstrate the daytime advection of pollutants into a lake-filled valley adjoining a broad urbanized coastal valley. On three separate days (immediately before, during, and after a pollutant episode), elevated concentrations of ozone $\left(\mathrm{O}_{3}\right)$ in the narrow tributary valley could be attributed to the advection of pollutants northward from sources in the LFV (primarily metropolitan Vancouver). On 5 August, the highest concentrations of $\mathrm{O}_{3}$ observed in the region during the entire episode were observed over the tributary lake. Simple Lagrangian mass budget calculations suggest that the unusually high concentrations observed on 5 August over the lake were physically reasonable and consistent with the known chemistry of the air advected into the valley. They also indicate that reductions in $\mathrm{O}_{3}$ flux divergence during the overlake trajectory in the Pitt Valley, primarily as a result of reduced surface deposition, may contribute to the relatively high concentrations observed in the tributary valley. Observations immediately after the episode show that chemically aged polluted air masses can persist within the tributary valleys from the previous day. These results have implications for the understanding of air pollution in other regions of complex terrain and show that the predominance of daytime upvalley pollutant transport in such tributary valleys is likely to have significant impacts on the local ecology and visibility.
\end{abstract}

\section{Introduction}

Large cities and their surrounding regions often experience degraded air quality due to the formation of photochemical smog resulting primarily from automobile emissions of oxides of nitrogen and hydrocarbons. These "precursor" pollutants are transformed in the presence of sunlight into a variety of pollutants [including ozone $\left(\mathrm{O}_{3}\right)$ and fine particles] that can be deleterious to human health and vegetation (Seinfeld 1989). The Lower Fraser Valley (LFV), with rapidly growing metropolitan Vancouver (population approximately 1.7

Corresponding author address: Dr. I. G. McKendry, Department of Geography, 251-1984 West Mall, University of British Columbia, Vancouver, BC, V6T 1Z2, Canada.

E-mail: ian@geog.ubc.ca million) at its western end, experiences such photochemical pollution during summer months. The $\mathrm{O}_{3}$ concentrations exceed the national ambient air quality hourly objective of $82 \mathrm{ppb}$ at one or more of the 24 monitoring stations within the LFV on approximately 8 days per summer (Pryor et al. 1995). Such exceedances are typically single-day events and are associated with a strong ridge of high pressure developed over the region (McKendry 1994; Pryor et al. 1995). Primary emission sources are mainly associated with the transportation sector in the western portion of the LFV.

Around coastal cities, the transport and dispersion of pollutants is often strongly affected by local winds, such as sea and land breezes. In complex terrain, valley and slope circulations also play important roles (Oke 1987). Consequently, in the daytime, urban pollutants may be advected inland from coastal plains into adjoining valleys by upvalley winds and sea breezes (e.g., Kurita et 


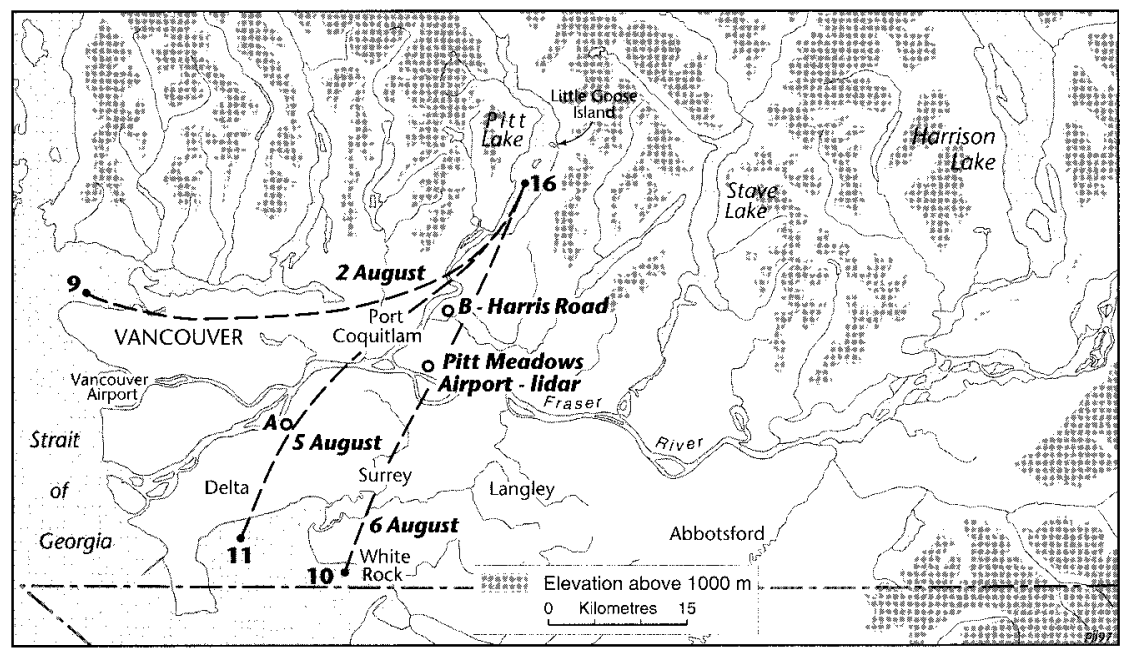

FIG. 1. Map of the Lower Fraser Valley showing sites mentioned in the text and surface backtrajectories ending at 1600 LST over Pitt Lake for 2, 5, and 6 August 1993.

al. 1985; Douglas and Kessler 1991). At night, the reverse occurs, and pollutants are advected out of valleys and perhaps offshore by downvalley winds and land breezes (Banta et al. 1997; Douglas and Kessler 1991). These diurnally reversing circulations create potential for not only seriously degraded air quality at remote sites but also for pollutants from one day to recycle and contribute to ground-level concentrations over urbanized areas the following day. Despite observational studies in a number of urbanized settings, the role of valleys adjoining coastal urbanized lowlands in the regional budget of pollutants is not well understood. Of particular interest is the extent to which nearby valleys act as a sink for pollutants emanating from an urbanized coast and whether they contribute to the recirculation of pollutants via diurnally reversing circulations (Banta et al. 1997).

Previous studies of pollutant transport in the vicinity of Vancouver have largely ignored tributary valleys and focused on the role played by thermotopographic circulations (notably land/sea and valley breezes) operating within the LFV, the broad, steep-sided, east-westoriented coastal valley in which the city is located (Steyn and McKendry 1988). In the LFV (Fig. 1), pollutant transport during episodes of poor summertime air quality is dominated by the sea breeze that develops during stagnating anticyclonic conditions (McKendry 1994; Steyn and Faulkner 1986) and advects the urban plume eastward from Vancouver. Consequently, the highest concentrations of $\mathrm{O}_{3}$ within the surface monitoring network (which is wholly located within the LFV) have historically occurred in the Pitt Meadows region (downwind of major sources of precursors in Vancouver) and the eastern LFV. Recent modeling studies indicate that daytime flow into the north-south-oriented tributary valleys along the northern edge of the LFV also carries with it pollution emanating from metropolitan Vancou- ver (Steyn and Miao 1995). In particular, the largely unpopulated, forested, and lake-filled Pitt Valley immediately downwind of the city (Fig. 1) produces strong daytime upvalley and nocturnal downvalley flows in simulations. As a result, simulated pollutant trajectories move into and out of this valley in a diurnal cycle (Steyn and Miao 1995). Other results (Banta et al. 1997) from Pacific '93 (the intensive field campaign on which this study reports) show that Pitt Valley produces strong nocturnal drainage with a pollutant signature consistent with an urban (i.e., greater Vancouver) source. Interestingly, this flow is found to be depleted in $\mathrm{O}_{3}$, an effect attributed to nocturnal deposition of $\mathrm{O}_{3}$ along valley slopes and also observed in valleys in Switzerland (Broder and Gygax 1985). A potentially significant sitespecific aspect of the LFV region is the presence of long finger lakes in virtually all of the adjoining valleys. For $\mathrm{O}_{3}$, water surfaces are known to reduce deposition rates considerably below those observed over terrestrial surfaces (Galbally and Roy 1980). Consequently, overwater trajectories may affect the budget of pollutants within the boundary layer.

A moderate episode of photochemical air pollution occurred in southwestern British Columbia from 1 to 6 August 1993 during an intensive field campaign designed to improve understanding of the meteorology and chemistry of photochemical pollution in the region. The objective of this paper is to decribe a set of observations from this period that corroborate modeling results (Steyn and Miao 1995), which highlighted the potential for daytime advection of the Vancouver urban plume into the Pitt Valley. By exploiting the same rich Pacific ' 93 dataset used by Banta et al. (1997), this study complements their description of nocturnal flows in the same valley by confirming pollutant transport into the Pitt Valley and elucidating processes affecting daytime concentrations within the valley. Finally, a simple mass 
budget approach is used to assess whether high concentrations observed over Pitt Lake are physically reasonable and to provide a first-order assessment of the relative roles of the photochemical production and surface deposition in influencing observed concentrations within the valley. The air pollution meteorology of the Pitt Valley described here, and by Banta et al. (1997), highlights the important effect of complex terrain in influencing the mass budget of photochemical pollutants along urbanized coasts.

\section{Methods}

Pacific '93 was a multiagency field campaign designed to elucidate the meteorology and chemistry of photochemical air pollution episodes in the LFV and environs (Steyn et al. 1997). The National Oceanic and Atmospheric Administration/Environmental Technology Laboratory (NOAA/ETL) scanning Doppler lidar was located to the south of Pitt Lake adjacent to Pitt Meadows Airport and was able to scan the atmosphere over a range extending into the mouth of the Pitt Valley (Fig. 1). A description of the lidar and its application in complex coastal terrain is provided in Banta et al. (1993), and Banta et al. (1997). Particularly useful in the context of this study were a series of vertical slice, or range-height indicator (RHI) scans, directed toward the Pitt Valley. In RHI mode, the lidar remains at a constant azimuth angle while scanning in elevation. This produces a high-resolution vertical slice (distance versus height) of wind velocity and backscatter data (an index of aerosol loading) to a horizontal distance of approximately $15 \mathrm{~km}$ from the lidar.

Vertical tethered balloon soundings of meteorological variables and $\mathrm{O}_{3}$ to approximately $1000 \mathrm{~m}$ above ground level (AGL) were conducted at Harris Road, at the mouth of the Pitt Valley, and Little Goose Island on Pitt Lake (Fig. 1), during the photochemical pollution episode from 1 to 6 August 1993. The island location permitted examination of the valley circulations at a range considerably beyond that captured by lidar at the valley entrance. Vertical sounding operations at each site consisted of deployment of an Atmospheric Instrumentation Research Inc. (AIR) tethersonde (TS-3A-SPH) with ozonesonde (OZ-3A-T) beneath a $5-\mathrm{m}^{3}$ helium-filled balloon and were restricted to daylight hours to meet aircraft safety considerations. In total, 37 soundings were made at Harris Road in the 6-day period, while at the Pitt Lake site, 16 soundings were made mostly on 2 and 5 August. Tethersonde flights were intermittant at both sites due to logistical problems and strong winds that occasionally halted operations. Further details are provided in McKendry et. al. (1997).

Measurements of a wide variety of chemical species were also made at Harris Road during Pacific '93. This permitted analysis of the chemical signature of pollutants transported into and out of the Pitt Valley, as well as a check on ground-level $\mathrm{O}_{3}$ measurements from the ozonesondes. The range of "fast chemistry" instrumentation at Harris Road is described in detail by Li et al. (1997) and Steyn et al. (1997). For the species used in this study, nitrogen oxide (NO) and nitrogen dioxide $\left(\mathrm{NO}_{2}\right)$ were measured by $\mathrm{O}_{3}$-chemiluminescence, $\mathrm{O}_{3}$ by UV absorption, carbon monoxide $(\mathrm{CO})$ by gas correlation, and peroxyacetal nitrate (PAN) by gas chromatography using electron capture detection.

Aircraft [National Research Council (NRC) Convair 580] observations during Pacific ' 93 are described in detail in Steyn et al. (1997). Of the multitude of flight legs undertaken, low-level observations (300-500 m) over Pitt Lake and vertical profiles in the vicinity of Pitt Meadows provide valuable ancillary data relevant to understanding air quality and meteorology in the tributary valleys. In particular, simultaneous observations of $\mathrm{O}_{3}, \mathrm{NO}_{y}, \mathrm{NO}$, and aerosol (in the size range 0.2-3 $\mu \mathrm{m}$ ) along a horizontal track are utilized to give a broader perspective on air quality in the area than possible with tethersonde observations alone.

To assess whether concentrations observed over Pitt Lake were physically reasonable and to provide a firstorder estimate of the relative roles of the photochemical production and surface deposition in influencing observed concentrations within the valley, a simple mass budget (within a Lagrangian framework) was calculated for 5 August 1993. This approach is based on a boundary layer slab model (Lenschow et al. 1981) and assumes that the air column sampled by tethersonde at Harris Road is subsequently sampled by the second tethersonde at Little Goose Island (25 km to the northeast). The mass budget approach and calculations are described in detail in the appendix. To apply this model in the context of the Pitt Valley, several assumptions were necessary. First, horizontal homogeneity and zero mean vertical velocity were deemed to be reasonable, simplifying assumptions given the breadth of the valley (measurements are made on the valley floor several kilometers from the base of slopes) and zero slope (Pitt Lake is near sea level) along the section of the valley considered here. Second, in using only two measurement sites, it is assumed that only the along-valley component of horizontal flux divergence is resolved in the air columns moving across Harris Road and past the Pitt Lake site. We consider this to be a reasonable firstorder approximation in this long, rather narrow valley.

\section{Results}

\section{a. Overview}

During the intensive observational period from 1 to 6 August 1993, upper-level synoptic flow conditions favored the development of above average $\mathrm{O}_{3}$ concentrations but were not conducive to the development of a major $\mathrm{O}_{3}$ episode (Pottier et al. 1997). The latter generally occurs when an upper-level ridge is positioned over the region producing stagnation, subsidence, and 
the ancillary conditions necessary for elevated $\mathrm{O}_{3}$ (McKendry 1994; Pottier et al. 1997). In this case, the upper-level ridge was positioned to the west of British Columbia producing a predominately northerly flow. However, surface heating during the period was sufficient to produce a thermal trough along the west coast, a characteristic feature of elevated $\mathrm{O}_{3}$ episodes (McKendry 1994). Because of the relatively weak longwave ridge of high pressure during the episode described here, traveling shortwave ridges and troughs propagating along the edge of the ridge induced significant day-today variability in the local meteorological conditions (e.g., stability, subsidence, and winds) that modulate pollutant concentrations (Pottier et al. 1997; Hayden et al. 1997).

The course of meteorological variables and relevent pollutants at Harris Road during the observational period is shown in Fig. 2. Maximum temperatures (Fig. $2 \mathrm{~b}$ ) and $\mathrm{O}_{3}$ concentrations (Fig. 2c) occurred on $4 \mathrm{Au}$ gust after a 3-day period of successively higher daytime maximum temperatures. The component of wind velocity up Pitt Lake (positive values represent upvalley flow with the Pitt Valley axis assumed to be aligned $225^{\circ}-45^{\circ}$ ) shows a consistent pattern of upvalley winds during the afternoon. This pattern is representative of long-term wind observations from the mouth of the Pitt Valley that show a summer afternoon (1200-1800 LST) upvalley flow frequency of $77 \%$. The relatively short period of downvalley flow in the evening shown in Fig. 2a is also consistent with long-term observations. Banta et al. (1997) note that, during this period, surface winds at Harris Road were generally light and variable overnight (probably due to localized drainage flows) but were overlaid by a persistent downvalley flow. Strong downvalley flow on the early evening of 4 August was associated with a localized thunderstorm that moved along the northern edge of the LFV. A shift to low-level southeasterly flow on the evening of 5/6 August was associated with the propogation of low-level coastally trapped disturbances into the region and marked the end of the moderate air pollution episode (McKendry et al. 1997).

Carbon monoxide (Fig. 2f) is a species that is relatively chemically inert in the atmosphere and, consequently, provides an effective means of assessing the effects of dilution in the atmosphere (assuming relatively consistent emission patterns). Relatively high concentrations evident on 3 and 4 August and to a lesser extent on 5 August therefore reflect the reduced dilution associated with low mixing depths (Hayden et al. 1997) and relatively light winds under the ridge of high pressure. The reduction in dilution associated with the synoptic-scale meteorological pattern is also apparent in photochemically active precursor species (e.g., NO, Fig. 2e). These show elevated concentrations on 3-5 August associated with the injection of fresh precursors from the early morning traffic peak. Later in the day, concentrations decrease due to photochemistry, reduced
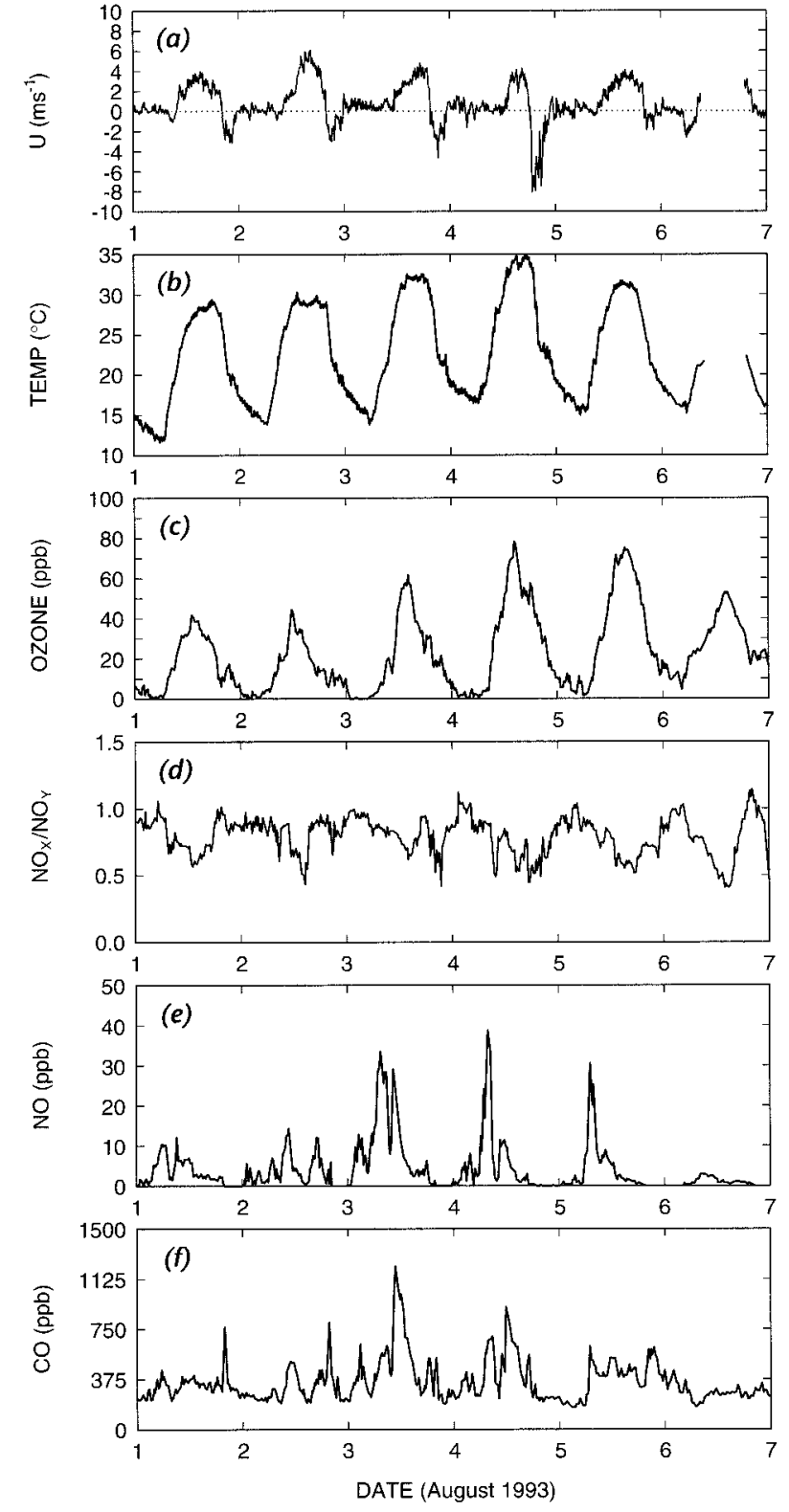

FIG. 2. Time series of meteorological variables and chemical species at Harris Road for 1-6 August 1993 showing (a) upvalley wind component (upvalley is positive with valley oriented $235^{\circ}-45^{\circ}$ ), (b) surface air temperature, (c) ozone $\left(\mathrm{O}_{3}\right)$ concentration, (d) $\mathrm{NO}_{x} / \mathrm{NO}_{y}$ ratio, (e) NO concentration, and (f) $\mathrm{CO}$ concentration. Note missing meteorological data on 6 August.

emission, and enhanced mixing. High concentrations of precursor species on 3-5 August were responsible for buildup of $\mathrm{O}_{3}$ concentrations during the moderate episode.

The ratio of $\mathrm{NO}_{x}$ (the sum of $\mathrm{NO}$ and $\mathrm{NO}_{2}$ ) to $\mathrm{NO}_{y}$ (the sum of all odd-nitrogen species, e.g., including PAN and $\mathrm{HNO}_{3}$ ) provides a useful measure of the "chemical age" of the pollutant mass (Banta et al. 1997). When this ratio is high (greater than 0.9), it implies that most of the $\mathrm{NO}_{y}$ is reactive nitrogen oxides $\left(\mathrm{NO}\right.$ and $\left.\mathrm{NO}_{2}\right)$ 
and therefore the air mass contains high concentrations of fresh pollution. Low values of $\mathrm{NO}_{x} / \mathrm{NO}_{y}$ (less than or equal to 0.6 ) suggest air that is chemically aged with most reactive nitrogen oxides, having been transformed to stable end products. For most of the episode (1-5 August) the ratio remained well above 0.6 (Fig. 2d), especially overnight (due to lack of photochemistry and local sources of $\mathrm{NO}_{x}$ ) and in the morning (fresh injections of $\mathrm{NO}_{x}$ ). This suggests that during the daytime on 1-5 August, polluted air masses passing across the Harris Road site and into Pitt Lake were photochemically active. Only in mid- to late afternoon, when photochemistry had consumed precursors and created more stable end products, did ratios drop below 0.6. With the change in weather conditions on the night of 5/6 August, the ratio shifts to quite a different pattern. On 6 August, values of $\mathrm{NO}_{x} / \mathrm{NO}_{y}$ drop below 0.5 from midmorning through late afternoon. This suggests that the air passing into Pitt Valley on this day was chemically aged and that above-average $\mathrm{O}_{3}$ concentrations were most likely associated with the downmixing of ozone from an elevated layer persisting from the previous day (see Fig. 6) rather than significant photochemical production (McKendry et al. 1997).

Crude back-trajectories based on hourly surface wind observations for 2, 5, and 6 August 1993 beginning at 0900, 1100, and 1000 LST and ending at 1600 LST are shown in Fig. 1 and provide a background to the detailed discussion presented below. On each of the days, the trajectories indicate daytime flow into Pitt Valley from the LFV. On 2 August, back-trajectories for air parcels arriving over Pitt Lake at 1600 LST indicate that pollutants observed in the Pitt Valley during the afternoon most likely emanated from sources along the northern edge of the LFV, including the city of Vancouver. On 5 and 6 August, the late afternoon trajectories reflect more southwesterly to southerly flow and pass over primary emission sources in the southern and eastern municipalities (e.g., Surrey, Delta, Port Coquitlam). Moderate winds associated with the latter two trajectories also suggest the possibility that a proportion of the pollutant load may have emanated from over the southern Georgia Strait where chemically aged pollutants may accumulate as a result of nocturnal offshore flow from the LFV (McKendry et al. 1997).

A series of afternoon vertical profiles of lidar backscatter and radial velocity at the mouth of the Pitt Lake valley, 8-9 km to the north of Pitt Meadows Airport, not only confirm the upvalley flow depicted in Fig. 2 but also show its vertical structure and aerosol loading (Fig. 3). Profiles all show low-level positive radial velocities, indicating flow into the valley. On 2 August, this upvalley flow lay beneath a layer of downvalley flow aloft associated with synoptic-scale northeasterly flow. Later in the episode, upper-level flow shifted to the west and this downvalley component aloft was not observed in the Pitt Valley (Pottier et al. 1997). From 2 until 5 August (note data are missing for 3 August) the strong low-level upvalley flow was associated with the high aerosol backscatter indicative of the advection of polluted air into the valleys. High backscatter was observed on 5 August when highest ground-level $\mathrm{O}_{3}$ concentrations were also observed in the LFV (Steyn et al. 1997). On both 4 and 5 August the highest aerosol content was associated with the strong upvalley flow closest to the surface. On 6 August, peak backscatter occurred in an elevated layer of aerosol at 350-500 m AGL.

In summary, daytime flow into the Pitt Valley from the LFV occurs frequently during summer days and advects polluted air into the valley. However, the trajectory analysis highlights the extent to which air reaching the Pitt Valley may follow quite different paths and therefore exhibit different pollutant histories. Air quality in the Pitt Valley during Pacific '93 will now be examined in greater detail with emphasis on 2, 5, and 6 August when intensive tethersonde observations were available.

\section{b. Observations of daytime advection of pollutants into tributary valleys}

\section{1) 2 August 1993: EARly ePISODE}

An upper-level trough deepened over the LFV on 2 August, producing a relatively strong northerly flow along the Georgia Strait and west to northwesterly flow over the western LFV. Meanwhile, the eastern valley experienced northeasterly outflow winds and temperatures that reached $32^{\circ} \mathrm{C}$ at Abbotsford during the afternoon.

In Fig. 4, isopleths of upvalley wind velocity, potential temperature, and $\mathrm{O}_{3}$ concentration for the period 0800-2000 LST are presented to show the temporal evolution of vertical structure over Pitt Lake. Early morning winds (0800-1000 LST) show the start of upvalley flow near the surface and downvalley flow aloft with a local maximum (up to $6 \mathrm{~m} \mathrm{~s}^{-1}$ ) in the strongly stable layer from 200 to $400 \mathrm{~m}$ (Fig. 4a). The latter represents the decaying nocturnal flow regime described by Banta et al. (1997). The shallow layer of upvalley flow already present by 0830 LST grew deeper as the mixed layer increased to a maximum depth of approximately $600 \mathrm{~m}$ in late afternoon. Above the mixed layer, the flow had a persistent downvalley component associated with predominant synoptic-scale northeasterly flow. Throughout the day, the relatively cool lake surface (approximately $18^{\circ} \mathrm{C}$ ) maintained a shallow surface-based inversion. This stable surface layer may have contributed to the low-level upvalley wind maximum of 4-5 $\mathrm{m} \mathrm{s}^{-1}$ (100-300 $\mathrm{m}$ above lake level) during the afternoon. However, observations elsewhere in the LFV suggest that this low-level "jet" was present across a significant proportion of the region. In late afternoon (1855 LST), upvalley flow was abruptly replaced by downvalley flow at the surface over Pitt Lake in what seems to be a regular pattern within the Pitt Valley (Ban- 


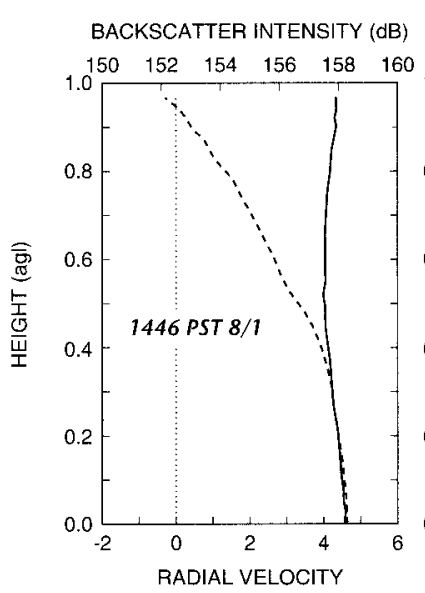

BACKSCATTER INTENSITY (dB) BACKSCATTER INTENSITY (dB)
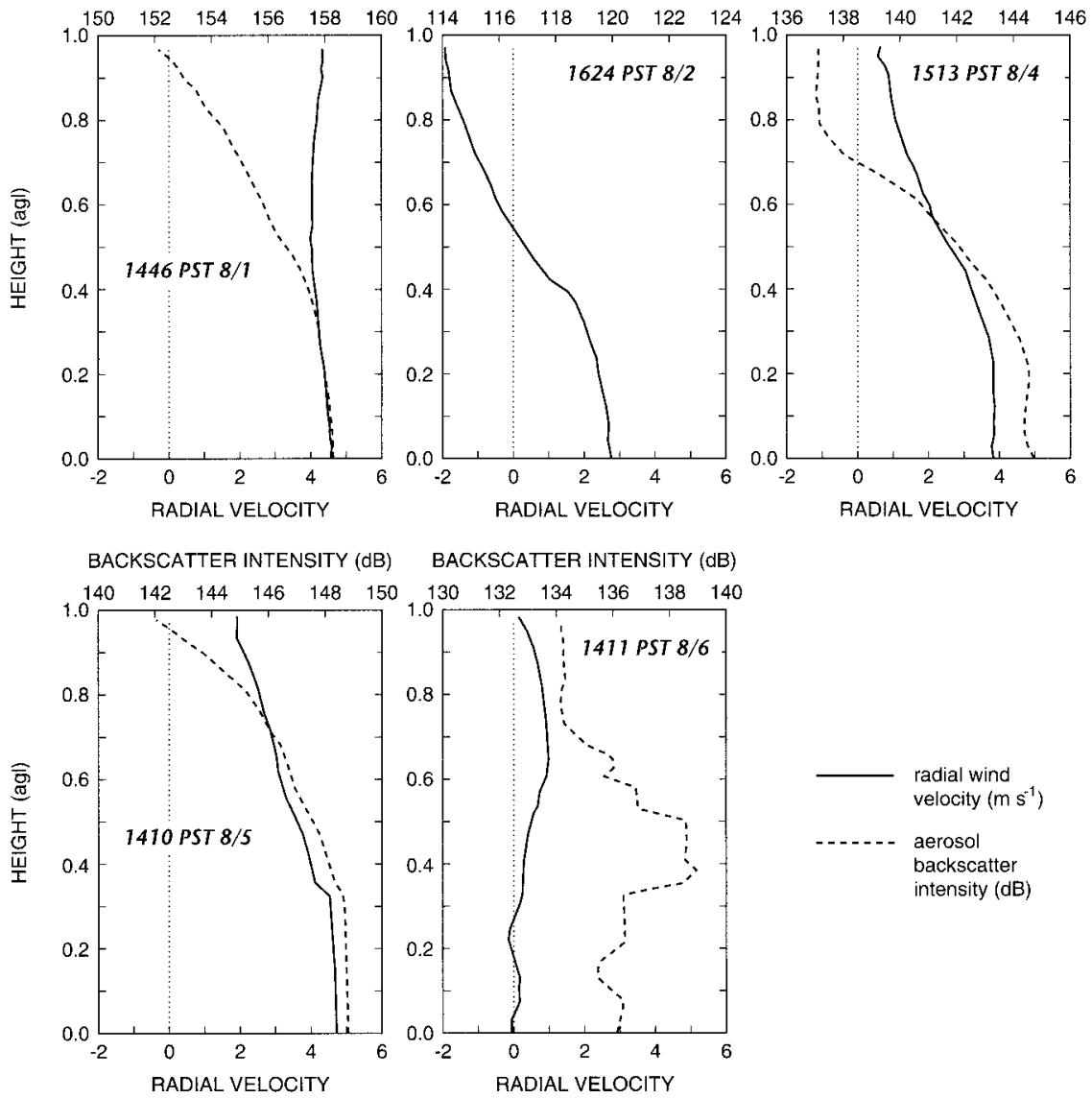

BACKSCATTER INTENSITY (dB)
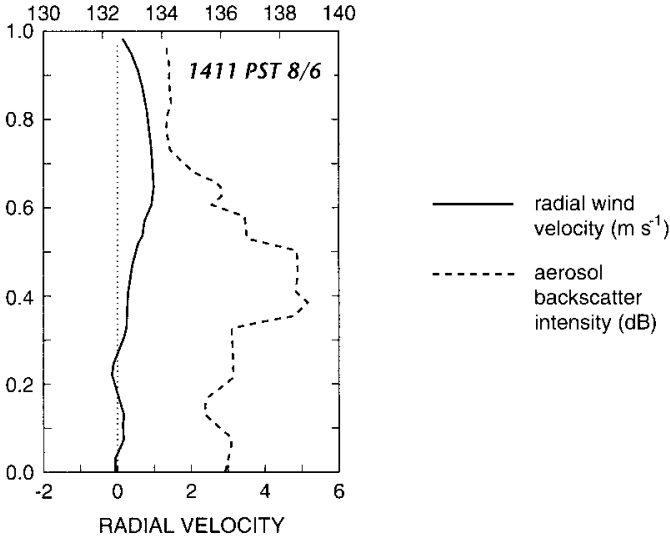

FIG. 3. Profiles of radial wind velocity (solid lines: units are in meters per second with positive values representing flow away from the lidar and into Pitt Valley) and aerosol backscatter intensity (dashed lines: unit are in decibels) averaged over $1 \mathrm{~km}$ at $8-9 \mathrm{~km}$ from lidar site (Pitt Meadows Airport, Fig. 1).

ta et al. 1997). This cycle was evident on many days during Pacific '93 and on all days of the photochemical pollution episode.

In the early morning, $\mathrm{O}_{3}$ isopleths (Fig. 4b) showed relatively clean air over Pitt Lake with little vertical variation in $\mathrm{O}_{3}$ concentrations. Concentrations then increased rapidly from 1300 to 1400 LST in association with a marked strengthening of the upvalley flow. The rapid increase on $\mathrm{O}_{3}$ concentration likely represents the leading edge of the urban "plume" as it was advected up the valley. In the midafternoon, $\mathrm{O}_{3}$ concentrations reached $60 \mathrm{ppb}$ within the Pitt Valley in a layer from 200 to $500 \mathrm{~m}$ above the lake. During this time, profiles also showed a sharp decrease in $\mathrm{O}_{3}$ concentration across the top of the mixed layer (between 600 and $700 \mathrm{~m}$ ).

\section{2) 5 August 1993: LAte ePISOdE}

On 4 August, the later afternoon was characterized by unstable conditions associated with the passage of a shortwave trough that induced thunderstorm activity along the northern edge of the LFV. However, by 5
August, the LFV was again under the influence of synoptic conditions conducive to the development of photochemical pollution. Maximum surface air temperatures reached $29^{\circ} \mathrm{C}$ at Vancouver airport and $30^{\circ} \mathrm{C}$ at Abbotsford. Within the LFV surface-monitoring network, maximum hourly average $\mathrm{O}_{3}$ concentrations reached $83 \mathrm{ppb}$ at Abbotsford in late afternoon. Next highest surface concentration was 73 ppb at Harris Road at 1554 LST.

Selected tethersonde profiles from Pitt Lake and Harris Road are shown in Fig. 5. (Note: due to a strong afternoon low-level jet, tethersonde operations were intermittent and ultimately curtailed at both sites. Consequently, the time evolution of profile variables is not well resolved for this case.) Early morning wind profiles from Pitt Lake (0635 LST, Fig. 5a) show downvalley outflow extending to approximately $700 \mathrm{~m}$ above the lake with strongest outflow immediately above the shallow mixed layer (Fig. 5b). Ozone concentrations were low at this time through the entire depth of the sounding (Fig. 5c) and suggest that the valley was flushed of pollutants. This was most likely the result of the late 
Pitt Lake, 2 August, 1993
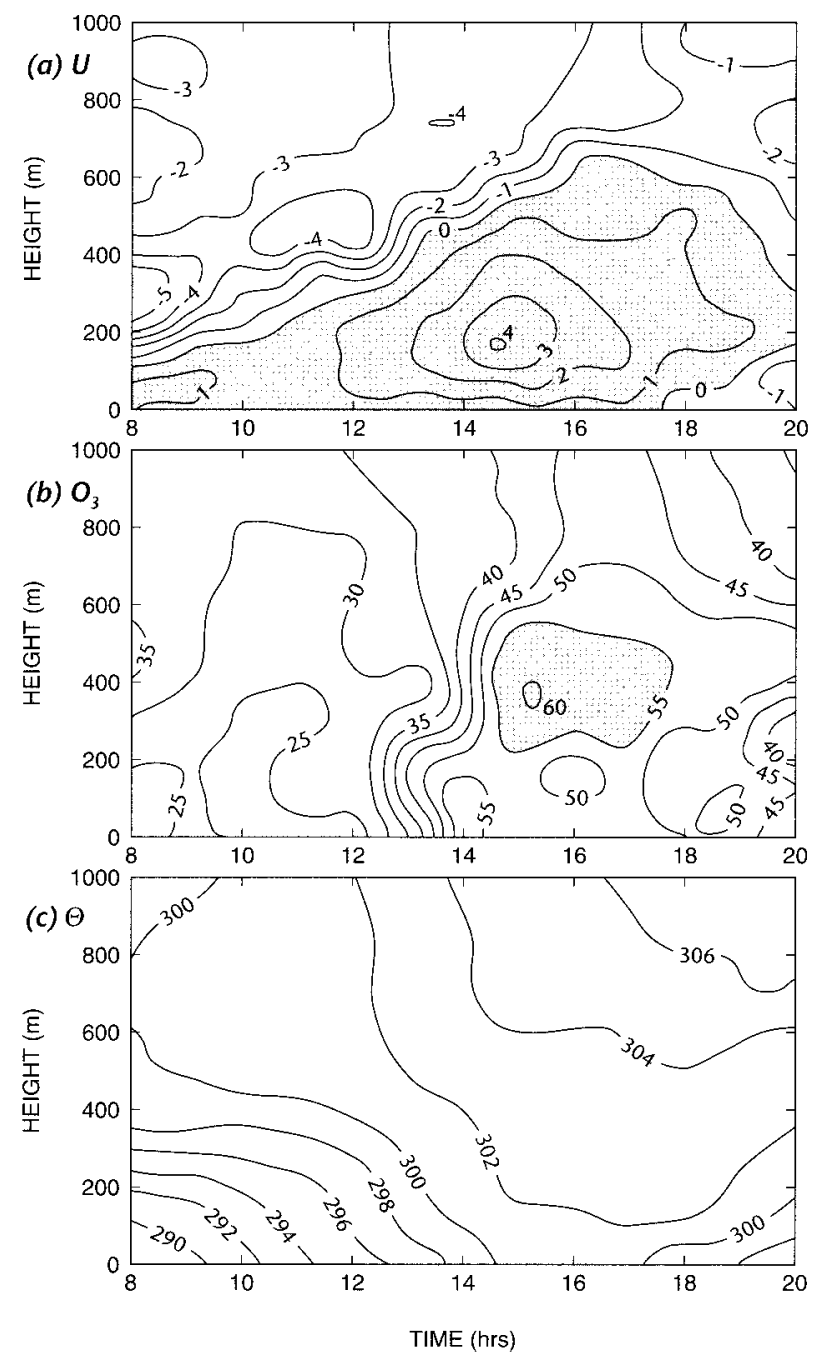

FIG. 4. Time-height plots showing isopleths of (a) the upvalley component of wind speed (positive values are shaded and represent upvalley flow), (b) $\mathrm{O}_{3}$ (ppbv) concentration, and (c) potential temperature $(\mathrm{K})$ based on tethersonde profiles from Little Goose Island on Pitt Lake for 2 August 1993. Contours are based on data from nine tethersonde flights giving 18 separate profiles.

afternoon thunderstorm and associated strong outflow the previous day (Fig. 2a). Winds switched to upvalley flow in the Pitt Valley by 0730 LST and strengthened to greater than $6 \mathrm{~m} \mathrm{~s}^{-1}$ by midafternoon (Fig. 5a, 1430 LST). As there were no balloon operations at Pitt Lake in late morning, the manner in which $\mathrm{O}_{3}$ concentrations increased is unclear. However, by 1430 LST, an ozone concentration of $111 \mathrm{ppb}$ was observed at $300 \mathrm{~m}$ within the strong upvalley flow that halted tethersonde operations. This was the highest concentration recorded in the valley during Pacific ' 93 and suggests that during episodes of elevated $\mathrm{O}_{3}$ concentrations in the LFV, Pitt Valley, and perhaps other tributary valleys may experience the worst air quality in the region. Midafternoon
$\mathrm{O}_{3}$ profiles from Harris Road and Langley (Fig. 5c) show $\mathrm{O}_{3}$ concentrations in the mixed layer of 60-70 $\mathrm{ppb}$, in broad agreement with concentrations at ground level but considerably less than those observed at Little Goose Island. The extent to which the unusually high concentrations observed in the tributary valley on this day were physically reasonable is addressed in section $3 \mathrm{c}$ below.

\section{3) 6 August 1993: Following EPISOde}

On 6 August, relatively cool conditions (low 20s degrees Celsius) prevailed in the LFV after a coastally trapped disturbance (bringing a low-level surge of cool marine air) propagated northward through the region (McKendry et al. 1997). The combination of a complete series of tethersonde observations from Harris Road and a late afternoon low-level aircraft mission across the LFV from White Rock northward across Pitt Lake (Fig. 1) provided on this occasion an unprecedented view of the horizontal and vertical structure of pollutants and meteorological variables within the valley system at the end of a pollutant episode.

Temporal evolution of the vertical structure of wind, ozone, and potential temperature at the mouth of the Pitt Valley (Harris Road) is shown in Fig. 6. Despite a surge of low-level southeasterly flow across the region overnight, early morning winds at Harris Road showed a significant downvalley component (Fig. 6a). This flow persisted above $500 \mathrm{~m}$ AGL until approximately midday but was replaced by upvalley flow in a shallow layer (approximately $200 \mathrm{~m}$ deep) at the surface by 0730 LST. Within the downvalley flow, morning $\mathrm{O}_{3}$ concentrations above $500 \mathrm{~m}$ exceeded $50 \mathrm{ppb}$. This suggests that the downvalley flow was relatively polluted, most probably with chemically aged air associated with photochemical activity the previous day (given that there are no sources of pollutants within Pitt Valley).

Early afternoon winds (Fig. 6a) at Harris Road showed relatively strong upvalley flow near the surface overlain by relatively light upvalley winds from 600 to $800 \mathrm{~m}$. The latter were associated with an inversion (Fig. $6 c$ ) in which ozone concentrations reached $90 \mathrm{ppb}$ in a well-defined elevated layer [origin of this layer is discussed in detail in McKendry et al. (1997)]. Within the same polluted layer, aircraft observations showed low $\mathrm{NO}$ and $\mathrm{NO}_{2}$ concentrations, suggesting that the layer was chemically aged and had likely persisted from the previous day (McKendry et al. 1997). Below this layer, $\mathrm{O}_{3}$ concentrations reached $60 \mathrm{ppb}$ in the moderately strong upvalley flow during midafternoon. The $\mathrm{O}_{3}$ isopleths at this time (Fig. 6b) show concentrations increasing with height through the mixed layer, a pattern attributed to vertical downmixing from the polluted layer above (McKendry et al. 1997). Injection of chemically aged pollutants into the mixed layer from the layer above probably contributed to the chemically aged sig- 

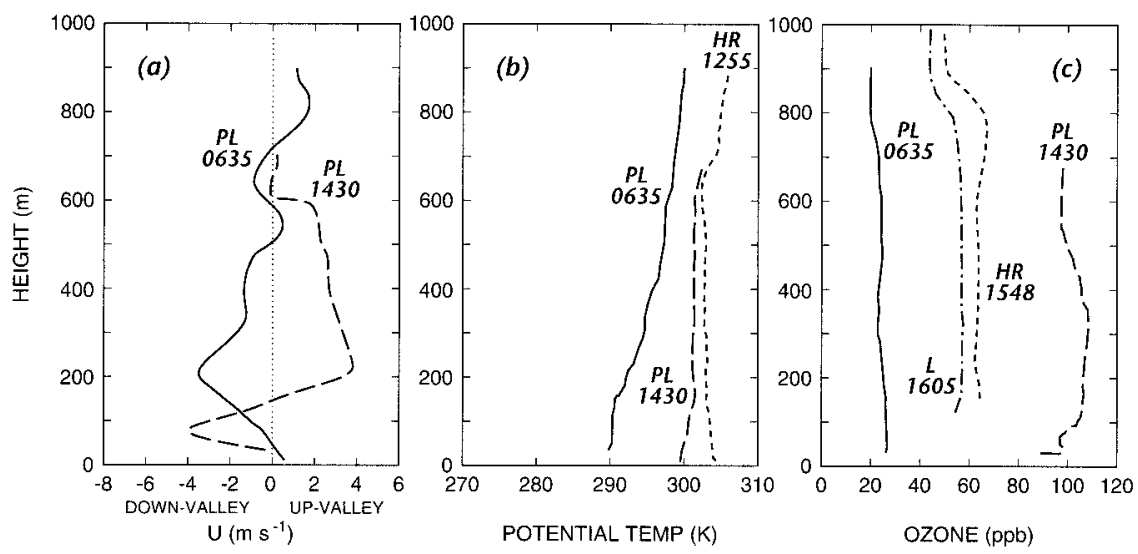

FIG. 5. Vertical profiles for 5 August 1993 of (a) upvalley wind component $(U)$ at Little Goose Island, Pitt Lake (PL), at 0635 and 1430 LST; (b) potential temperature $(\Theta)$ at 0635 and 1430 LST at PL and 1255 LST at Harris Road (HR); and (c) ozone concentration at 0635 and 1430 LST at PL, 1548 LST at HR, and 1605 LST at Langley (L).

nature $\left(\mathrm{NO}_{x} / \mathrm{NO}_{y}\right)$ of the afternoon surface fast chemistry measurements at Harris Road shown in Fig. 2.

A late afternoon, low-altitude (500-600 m) flight into the Pitt Valley (Fig. 7) complements the tethersonde observations by showing the horizontal extent and chemical character of polluted air advected into the valley system late in the episode. Concentrations of both aerosol and $\mathrm{O}_{3}$ show an increase with distance into the valley, a pattern frequently observed in the Pitt Valley during and subsequent to Pacific '93. However, the salient features of the transect in this case are the sharp increase in both $\mathrm{O}_{3}$ and aerosol concentrations at the south end of Pitt Lake, the associated sharp decrease in NO concentrations, and an initial drop, then increase, in $\mathrm{NO}_{y}$ concentrations. The same pattern was repeated on the flight out of the valley at a significantly lower altitude (400 m AGL, not shown here). This suggests that the aircraft remained within the mixed layer over Pitt Lake and below the elevated layer shown in Fig. 5. The abrupt transition at the south end of Pitt Lake suggests a transition to a different air mass with different initial pollutant loadings. Given the late (midday) transition to upvalley flow in the mixed layer apparent at Harris Road (Fig. 6a) together with the polluted nature of the morning outflow from the valley (Fig. 6b), it is possible that the mixed layer to the north of the south end of Pitt Lake represented chemically aged air advected into the valley the previous day, while polluted air to the south was associated with the combination of limited fresh photochemistry associated with the cooler conditions of 6 August and vertical downmixing from the chemically aged elevated layer.

\section{c. Mass budget calculations for 5 August}

Observations over Pitt Lake as described here for Pacific '93, and in subsequent field studies, suggest that concentrations of $\mathrm{O}_{3}$ during daytime are usually higher over the tributary lakes than within the LFV at comparable distances from the urban source. The first clear evidence of this pattern came from 5 August 1993 when the ozone concentration midway up Pitt Lake reached $111 \mathrm{ppb}$, by far the highest concentration observed in the entire region during Pacific '93. The availability of tethersonde observations from Harris Road on this day afforded the opportunity to carry out simple mass budget calculations (appendix) in order to 1) confirm that what appeared to be unusually high $\mathrm{O}_{3}$ values observed in Pitt Lake on 5 August were consistent with simple mass budget estimates and the observed chemistry of air advected into the Pitt Valley and 2) given the known low $\mathrm{O}_{3}$ deposition velocities during overwater trajectories (Galbally and Roy 1980), estimate the relative roles of $\mathrm{O}_{3}$ production and flux divergences in contributing to the high $\mathrm{O}_{3}$ concentrations.

In the Lagrangian analysis, it was assumed that the same column of air extending through the entire boundary layer observed by tethersonde at Harris Road at approximately $1230 \mathrm{LST}$ was observed $2 \mathrm{~h}$ later by the tethersonde ascent at the Pitt Lake site $(25.5 \mathrm{~km}$ to the northeast, assuming mean boundary layer winds of $4 \mathrm{~m}$ $\mathrm{s}^{-1}$ ). Over the 2-h period, mean $\mathrm{O}_{3}$ concentration in the PBL in the advected column increased from 70 to 100 $\mathrm{ppb}$, giving a mean change in concentration within the layer of $30 \mathrm{ppb}$ (or $15 \mathrm{ppb} \mathrm{h}^{-1}$ ). In traveling between the two sites it is estimated that 48 min was spent over land and 72 min over water. Furthermore, losses from surface deposition and entrainment at the top of the boundary layer were assumed to be distributed throughout the entire $600-\mathrm{m}$ boundary layer.

Assuming that the ozone concentrations in the column of air traveling from Harris Road to Little Goose Island increased at $15 \mathrm{ppb} \mathrm{h}^{-1}$, mass budget calculations (see appendix) give an estimated flux divergence [due to effects of entrainment at the top of the planetary boundary layer (PBL) and surface deposition] of $2.3 \mathrm{ppb} \mathrm{h}^{-1}$, 


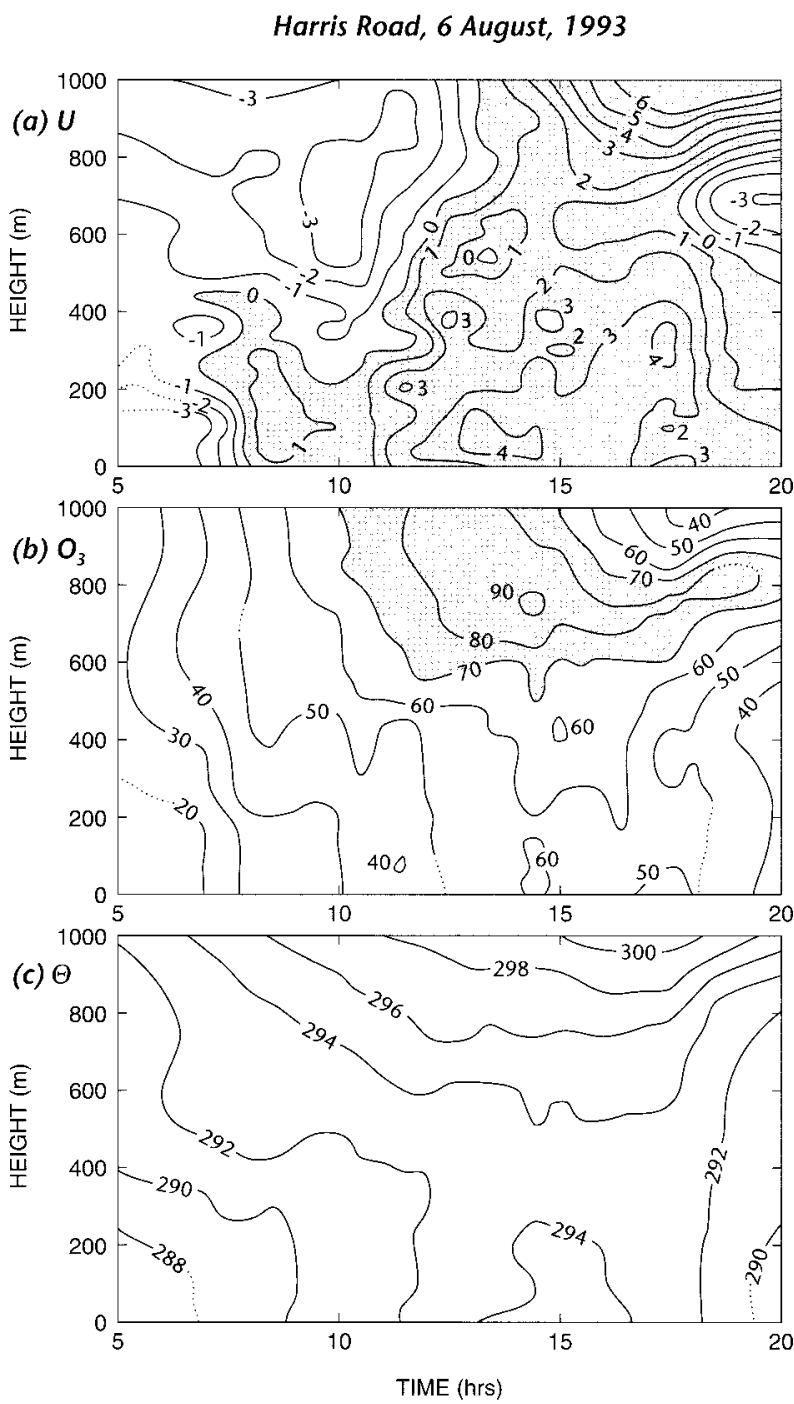

FIG. 6. Time-height plots showing isopleths of (a) the upvalley component of wind speed (positive values are shaded and represent upvalley flow), (b) $\mathrm{O}_{3}$ (ppbv) concentration, and (c) potential temperature $(\mathrm{K})$ based on tethersonde profiles from Harris Road for 6 August 1993.

and by residual, a net photochemical production rate $\left(Q_{s}\right)$ of approximately $17.3 \mathrm{ppb} \mathrm{h}^{-1}$. Chemical evidence from Harris Road, together with independent mass budget calculations (based on surface observations from Harris Road and farther south) suggest that this estimate of $Q_{s}$ is reasonable (see appendix). Together, these sources of evidence lend credibility to the rather high concentrations observed over Pitt Lake on 5 August and suggest that they were unlikely to result from significant measurement error.

In addition to confirming the role of photochemical production within the urban plume in contributing to high $\mathrm{O}_{3}$ concentrations in the Pitt Valley, the Lagrangian analysis suggests that relatively high $\mathrm{O}_{3}$ concentrations observed within the tributary valleys can in part be at-
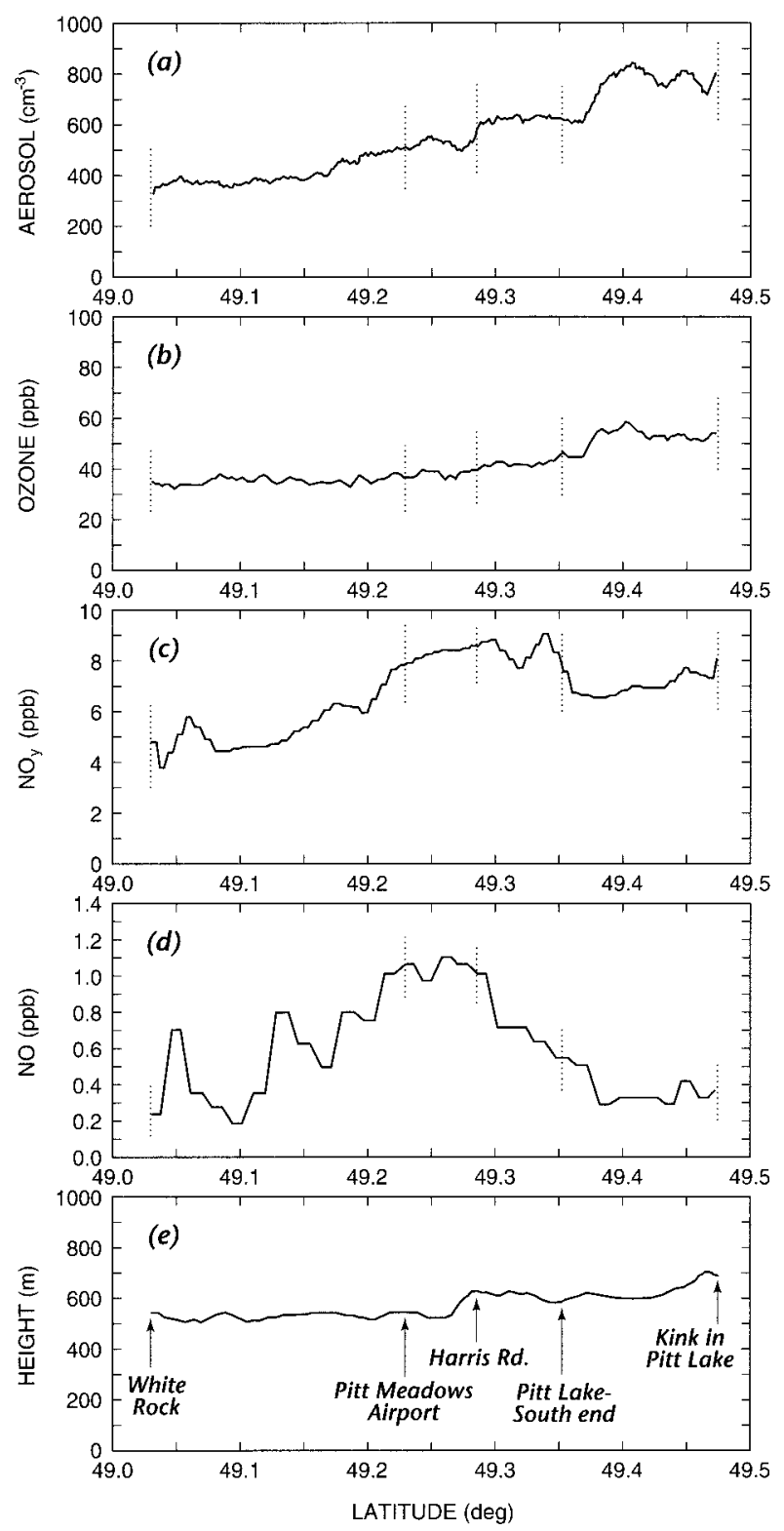

FIG. 7. NRC Convair aircraft observations of (a) dried aerosol $(>0.2$ $\mu \mathrm{m}$ ), (b) $\mathrm{O}_{3}$, (c) $\mathrm{NO}_{y}$, and (d) NO for the period 1614-1630 LST on 6 August 1993 for a south to north flight from White Rock into Pitt Valley Heights and landmarks are shown in (e). $\mathrm{NO}_{2}$ measurements were from an uncalibrated luminol instrument scaled to a slow response $\mathrm{NO}_{y}$ measurement (Ecophysics) assuming $\mathrm{NO}_{y}$ was all $\mathrm{NO}_{2}$.

tributed to low flux divergences during overlake trajectories. For a purely overland trajectory of the distance from Harris Road to Little Goose Island $(25.5 \mathrm{~km}$ with flux divergence of $2.23 \mathrm{ng} \mathrm{m}^{-3} \mathrm{~s}^{-1}$ ), the rate of change of $\mathrm{O}_{3}$ concentration (moving with the flow) is $13.3 \mathrm{ppb}$ $\mathrm{h}^{-1}$ (a rate of $15 \mathrm{ppb} \mathrm{h}^{-1}$ was observed for the trajectory over both land and water). For a solely overwater trajectory of $25.5 \mathrm{~km}$ (flux divergence estimated at 0.63 $\mathrm{ng} \mathrm{m}^{-3} \mathrm{~s}^{-1}$ ), the $\mathrm{O}_{3}$ concentration would increase by $16.1 \mathrm{ppb} \mathrm{h}^{-1}$, a rate of $2.8 \mathrm{ppb} \mathrm{h}^{-1}$ greater than for an 
overland trajectory. This indicates that over the long fingerlike lakes that occupy the tributary valleys of the LFV (Fig. 1), low surface deposition velocities may be one factor contributing to observed $\mathrm{O}_{3}$ concentrations that are higher than concentrations within the LFV at a comparable distance from the primary source of pollutants.

\section{Discussion and conclusions}

Upvalley flows into tributary valleys of the broad LFV play a significant role in the photochemical pollution cycle of the region in general and in the air quality of adjoining valleys in particular. The daytime circulations draw polluted air from the LFV into the smaller valleys where photochemical conversion processes continue to act on the pollutants. In this study, air quality and local daytime circulations in a tributary to the LFV were described for 3 days with quite different meteorological characteristics (before, during, and immediately after an $\mathrm{O}_{3}$ "episode"). On each of the afternoons, concentrations of $\mathrm{O}_{3}$ within the remote Pitt Valley were observed to be as high as or higher than in the LFV at the same time. Degraded air quality in the Pitt Valley is attributed primarily to photochemical production occurring within the polluted air mass as it was advected by upvalley winds from the source region in the western LFV and, to a lesser extent, by the reduction of depositional sink activity at the lake surface. Aircraft observations at the end of an episode also suggest that high concentrations in the valley may be associated with chemically aged pollutants persisting from the previous day. A simple analysis of the $\mathrm{O}_{3}$ mass budget within the Pitt Valley on 5 August 1993 indicates that high concentrations observed over the lake were physically reasonable. Furthermore, the overwater trajectory of polluted air masses in the tributary valleys was found to be a minor factor contributing to the observed high concentrations in the tributary valleys. This reduced depositional activity may help explain the relatively high $\mathrm{O}_{3}$ concentrations observed over lakes in the Swiss Alps (Wanner et al. 1993).

In addition to qualitatively validating the modeling results of Steyn and Miao (1995), these results show that the tributary valleys of the LFV may play an important role in the pollutant mass budget of the local region. The LFV is connected to several other larger tributary valleys including Stave Lake and the very large Harrison Lake to the east. Together these large valleys may process a significant volume of LFV air, producing excess concentrations of $\mathrm{O}_{3}$ during daytime but cleansing the outflow air of $\mathrm{O}_{3}$ and other pollutants at night (Banta et al. 1997). Although even the sign of the net effect over the diurnal cycle is in doubt, these processes may play a significant role in the mass budget of pollutants in the region. Further observations and a more detailed analysis of the processes contributing to the high concentrations in the valleys are needed as a prelude to modeling studies.
Despite remaining uncertainties, significant impacts on visibility and the local ecology of the forested watersheds adjoining the LFV are likely as a result of the transport and formation of photochemical oxidants in tributary valleys. Further research is required to ascertain the spatial extent and magnitude of exposure to atmospheric oxidants in the region.

Acknowledgments. This research was supported by the Natural Sciences and Engineering Research Council of Canada (NSERC), Atmospheric Environment Service, and the Canadian Institute for Research in Atmospheric Chemistry (CIRAC). We are grateful to Bobby Downs, Kate Stephens, Magdalena Rucker, Markus Kellerhals, and John Pisano for assistance with tethersonde operations. We also thank members of the lidar crews, including Janet Intieri, Mike Hardesty, M. J. Post, Ron Willis, Lisa Olivier, and Cui-Juan Zhu for analysis of lidar data. The assistance provided by Don Hastie and Corina Arias is also greatly appreciated. Thanks to Paul Jance for the preparation of the figures.

\section{APPENDIX}

\section{Mass Budget Calculations}

For any atmospheric constituent, $S\left(\mathrm{~kg} \mathrm{~m}^{-3}\right)$ assuming horizontal homogeneity for the turbulent flux terms and negligible mean vertical velocity, the budget is

$$
\frac{\partial \bar{S}}{\partial t}=Q_{s}-\bar{u} \frac{\partial \bar{S}}{\partial x}-\frac{\partial \overline{S^{\prime} w^{\prime}}}{\partial z},
$$

where $u$ is the mean wind aligned along the valley axis (in the $x$ direction), $w$ is the fluctuating component of vertical velocity, $z$ is the vertical coordinate, $t$ is time, and $Q_{s}$ is the source or sink of $S$. For $\mathrm{O}_{3}$, the rate of change in a given volume at a fixed location (term 1) is a result of $\mathrm{O}_{3}$ production or destruction within the volume (term 2), the mean horizontal advection (term 3 ), and the vertical flux divergence (term 4).

In a Lagrangian frame of reference and assuming horizontal homogeneity in flux divergence, Eq. (A1) becomes

$$
\frac{d \overline{\mathrm{S}}}{d t}=Q_{s}-\frac{\partial \overline{S^{\prime} w^{\prime}}}{\partial z},
$$

where the rate of change of $\mathrm{O}_{3}$ concentration (term 1) now refers to the changing concentration in a column of fixed volume (unit cross section) moving with the flow.

If the entire boundary layer is the volume considered, flux divergence is calculated on the basis of flux across the top of the mixed layer and deposition of $\mathrm{O}_{3}$ at the ground. The $\mathrm{O}_{3}$ destruction rate at the ground $F_{g}$ is given by

$$
F_{g}=\left(\mathrm{O}_{3}\right) r_{s}^{-1},
$$

where $r_{s}$ is the surface resistance to $\mathrm{O}_{3}$ uptake (Galbally 
TABLE A1. Estimates of parameters for mass budget calculations. In calculations it is assumed that $1 \mathrm{ppb} \mathrm{O}_{3}=1.980 \mu \mathrm{g} \mathrm{m}^{-3}$ at $25^{\circ} \mathrm{C}$ (Oke 1987), a good approximation in this context.

\begin{tabular}{lll}
\hline \hline$z_{i}$ & $600 \mathrm{~m}$ & From tethersonde profile \\
$w_{e}$ (land) & $0.02 \mathrm{~m} \mathrm{~s}^{-1}$ & Steyn and Oke (1982) \\
$w_{e}$ (water) & $0.01 \mathrm{~m} \mathrm{~s}^{-1}$ & Estimated \\
$r_{s}$ (land) & $160 \mathrm{~s} \mathrm{~m}^{-1}$ & Galbally and Roy (1980) \\
$r_{s}$ (water) & $1000 \mathrm{~s} \mathrm{~m}^{-1}$ & Galbally and Roy (1980) \\
$\Delta \mathrm{O}_{3}$ & $20 \mu \mathrm{g} \mathrm{m}^{-3}$ & From ozonesonde \\
$U$ & $4 \mathrm{~m} \mathrm{~s}^{-1}$ & From tethersonde \\
\hline
\end{tabular}

and Roy 1980). Previous studies (Galbally and Roy 1980; Wesely et al. 1981) suggest that $r_{s}^{-1}$ over grassland surfaces during daytime in the midlatitude Northern Hemisphere is approximately $160 \mathrm{~s} \mathrm{~m}^{-1}$, while over water surface $r_{s}^{-1}$ values are an order of magnitude higher (approximately $1000 \mathrm{~s} \mathrm{~m}^{-1}$ ). At the top of the boundary layer the flux of $\mathrm{O}_{3}$ can be calculated by

$$
F_{t}=w_{e} \Delta \mathrm{O}_{3},
$$

where $w_{e}$ is the entrainment velocity and $\Delta \mathrm{O}_{3}$ is the change in $\mathrm{O}_{3}$ concentration across the entrainment layer (Lenschow et al. 1981). Given typical entrainment velocities in the LFV of $0.02 \mathrm{~m} \mathrm{~s}^{-1}$ [Steyn and Oke (1982) calculated from $d z_{i} / d t$, where $z_{i}$ is the height of the mixed layer], then the flux divergence terms can be approximated for the region over land and water.

Parameters used in the mass budget calculations are shown in Table A1 and are based on best estimates from the literature or measured values for the region.

Given these simple assumptions for the 2-h trajectory and from (A2) the following is evident.

- Rate of change of $\mathrm{O}_{3}$ concentration in a fixed volume moving with the flow from Harris Road to Little Goose Island is given by

$$
\frac{d \bar{S}}{d t}=8.25 \mathrm{ng} \mathrm{m}^{-3} \mathrm{~s}^{-1}=15 \mathrm{ppb} \mathrm{h}^{-1}
$$

- Amount of $\mathrm{O}_{3}$ lost from the boundary layer across the top of the mixed layer and to the surface by deposition is estimated to be

$$
\begin{aligned}
\frac{\partial \overline{S^{\prime} w^{\prime}}}{\partial z}= & 1.27 \mathrm{ng} \mathrm{m}^{-3} \mathrm{~s}^{-1} \\
= & 2.3 \mathrm{ppbh}^{-1}\left(2.23 \mathrm{ng} \mathrm{m}^{-3} \mathrm{~s}^{-1}\right. \text { over land, } \\
& \left.0.63 \mathrm{ng} \mathrm{m}^{-3} \mathrm{~s}^{-1} \text { over water }\right) .
\end{aligned}
$$

- By residual [see Eq. (A2)], the net rate of photochemical production of $\mathrm{O}_{3}$ in the boundary layer in a fixed volume moving with the flow is therefore

$$
Q_{s}=9.52 \mathrm{ng} \mathrm{m}^{-3} \mathrm{~s}^{-1}=17.3 \mathrm{ppb} \mathrm{h}^{-1} .
$$

Chemical measurements at Harris Road on the early afternoon of 5 August provide important corroborative evidence for net production rates estimated by the model. First, relatively high concentrations of peroxy radi- cals (up to $20 \mathrm{pptv}$ ) and NO (up to $4 \mathrm{ppb}$ ) throughout the early afternoon suggest that the column of air considered in the Lagrangian analysis was chemically active and had a gross $\mathrm{O}_{3}$ production rate on the order of 30 $\mathrm{ppb} \mathrm{h}^{-1}$ (D. Hastie 1996, personal communication). Net production rates of the magnitude estimated here (17.3 $\mathrm{ppb} \mathrm{h}^{-1}$ ) would therefore not be unexpected when chemical destruction processes were considered. Second, the local rate of change of surface $\mathrm{O}_{3}$ at Harris Road measured by continuous monitor [the term on the left-hand side of Eq. (A1)] was $9.7 \mathrm{ppb} \mathrm{h}^{-1}$ from 1230 to 1430 LST. Given this value, Eq. (A1) can be solved independently for the net production rate $\left(Q_{s}\right)$ with advection calculated over the trajectory AB (Fig. 1) and the flux divergence over land estimated using parameters from Table A1. With advection based on the observed average early afternoon $\mathrm{O}_{3}$ gradient $(\mathrm{AB})$ of $18 \mathrm{ppb}$, and a mean wind speed of $2.1 \mathrm{~m} \mathrm{~s}^{-1}$ (based on available surface wind data in the vicinity of $\mathrm{AB}), Q_{s}$ is $19.9 \mathrm{ppb} \mathrm{h}^{-1}$. This value is in close agreement with $Q_{s}$ calculated using Eq. (A2) from Harris Road to Little Goose Island and suggests that the Lagrangian analysis is consistent with observations.

\section{REFERENCES}

Banta, R. M., L. D. Olivier, and D. H. Levinson, 1993: Evolution of the Monterey Bay sea-breeze layer as observed by pulsed Doppler lidar. J. Atmos. Sci., 50, 3959-3982.

—, and Coauthors, 1997: Nocturnal cleansing flows in a tributary valley. Atmos. Environ., 31, 2147-2162.

Broder, B., and H. A. Gygax, 1985: The influence of locally induced wind systems on the effectiveness of nocturnal dry deposition of $\mathrm{O}_{3}$. Atmos. Environ., 19, 1627-1637.

Douglas, S. G., and R. C. Kessler, 1991: Analysis of airflow patterns in the south-central coast air basin during the SCCCAMP 1985 intensive measurement periods. J. Appl. Meteor., 30, 607-631.

Galbally, I. E., and C. R. Roy, 1980: Destruction of ozone at the Earth's surface, Quart. J. Roy. Meteor. Soc., 106, 599-620.

Hayden, K. L., and Coauthors, 1997: The vertical chemical and meteorological structure of the boundary layer in the Lower Fraser Valley during Pacific '93. Atmos. Environ., 31, 2089-2105.

Kurita, H., K. Sasaki, and H. Muroga, 1985: Long-range transport of air pollution under light gradient wind conditions. J. Climate Appl. Meteor., 24, 425-434.

Lenschow, D. H., R. Pearson Jr., and B. B. Stankov, 1981: Estimating the $\mathrm{O}_{3}$ in the boundary layer by use of aircraft measurements of $\mathrm{O}_{3}$ eddy flux and mean concentration. J. Geophys. Res., 86, 7291-7297.

Li, S.-M., K. G. Anlauf, H. A. Wiebe, J. W. Bottenheim, P. B. Shepson, and T. Biesenthal, 1997: Emission ratios and photochemical efficiencies of nitrogen oxides, ketones and aldehydes in the Lower Fraser Valley during the summer Pacific '93 oxidant study. Atmos. Environ., 31, 2037-2048.

McKendry, I. G., 1994: Synoptic circulation and summertime groundlevel $\mathrm{O}_{3}$ concentrations at Vancouver, British Columbia. J. Appl. Meteor., 33, 627-641.

- , and Coauthors, 1997: Elevated $\mathrm{O}_{3}$ layers and vertical downmixing over the Lower Fraser Valley, B.C. Atmos. Environ., 31, 2135-2146.

Oke, T. R., 1987: Boundary Layer Climates. Methuen, 435 pp.

Pottier, J. L., S. C. Pryor, and R. M. Banta, 1997: Synoptic variability related to boundary layer and surface features observed during Pacific '93. Atmos. Environ., 31, 2163-2173.

Pryor, S. C., I. G. McKendry, and D. G. Steyn, 1995: Synoptic-scale 
meteorological variability and surface ozone concentrations in Vancouver, British Columbia. J. Appl. Meteor., 34, 1824-1833.

Seinfeld, J. H., 1989: Urban air pollution: State of the science. Science, 243, 745-752.

Steyn, D. G., and T. R. Oke, 1982: The depth of the daytime mixed layer at two coastal sites: A model and its validation. Bound.Layer Meteor., 24, 161-180.

- , and D. A. Faulkner, 1986: The climatology of sea breezes in the Lower Fraser Valley, B. C. Climatol. Bull., 20, 21-39.

- , and I. G. McKendry, 1988: Quantitative and qualitative evaluation of a three-dimensional mesoscale numerical model simulation of a sea breeze in complex terrain. Mon. Wea. Rev., 116, 1914-1926.

_ tory analysis during an air pollution episode in the Lower Fraser Valley, B.C. Trans. Regional Photochemical Measurement and Modelling Studies Conf., San Diego, CA, Air and Waste Manag. Assoc., 249-281.

, J. W. Bottenheim, and B. Thomson, 1997: Overview of tropospheric $\mathrm{O}_{3}$ in the Lower Fraser Valley, and the Pacific '93 field study. Atmos. Environ., 31, 2025-2035.

Wanner, H., T. Kunzle, U. Neu, B. Ihly, G. Baumbach, and B. Steisslinger, 1993: On the dynamics of photochemical smog over the Swiss Middleland-Results of the first POLLUMET field experiment. Meteor. Atmos. Phys., 51, 117-138.

Weseley, M. L., D. R. Cook, and R. M. Williams, 1981: Field measurement of small $\mathrm{O}_{3}$ fluxes to snow, wet bare soil, and lake water. Bound.-Layer Meteor., 20, 459-471. 